\title{
A Programmable Source Based on Multi-level Buck EIE inverter connected to a power factor correction stage composed by a single-phase hybrid rectifier
}

\author{
G. N. Souza ${ }^{1}$, D. B. Rodrigues ${ }^{1}$, G. B. de Lima ${ }^{2}$, L. C. G. de Freitas ${ }^{2}$, A. J. P. Rosentino Junior ${ }^{1}$, M. R. \\ M. Castillo ${ }^{1}$, F. A. M. Moura ${ }^{1}$, M. V. B. Mendonça ${ }^{1}$, R. R. de Lima ${ }^{1}$ and W. B. de Melo ${ }^{1}$ \\ ${ }^{1}$ Electrical Engineering Department, Federal University of Triângulo Mineiro, Uberaba - Minas Gerais, Brazil \\ Phone/Fax number:+005534 997932329, e-mail: madeleine.albertini@uftm.edu.br, danilo.rodrigues@uftm.edu.br \\ ${ }^{2}$ Electrical Engineering Department, Federal University of Uberlandia, Uberlandia - Minas Gerais, Brazil \\ Phone/Fax number:+005534 991584723, e-mail: gustavo.lima@ufu.edu.br, luis.freitas@ufu.edu.br
}

\begin{abstract}
This paper presents a power factor correction stage connected to a programmable source based on the Buck EIE converter Topology. The strategy used to ensure the unitary power factor is based on the use of the single-phase hybrid rectifier, which has the purpose of providing voltages at their outputs for the correct supply of the two cells that make up the Buck EIE converter. It was developed the computational simulation model, including the calculations of the passive elements and the control strategy applied to trigger the electronic switches.
\end{abstract}

Key words. Buck EIE, power factor, programmable source, hybrid rectifier, Sepic.

\section{Introduction}

Recently, the role of photovoltaic (PV) energy in the utility grid has increased with the sustained growth of PV technology and continuous decreases in the Price of PV products. Although PV energy is an abundant energy source, PV output power fluctuates according to the environmental conditions. This fluctuations cause negative effect on the power quality and reliability of a PV system.

Much of the electricity consumed in the world is from loads that require some kind of electronic power converter, on the other worlds, the energy is processed electronically before it is actually used for its intended purpose. Despite the fact that most countries provide end consumers with a sinusoidal voltage and that most electronic equipments operates on direct voltage, the use of AC-DC converters is required. However, after the electrical voltage generation, many devices adjust the voltage level through the use of DC-DC converters. The most common voltage sources are linear and switched sources, each having advantages and disadvantages over the other according to the desired purpose for the project.

Linear sources are widely used because of their high dynamic response, constructive simplicity and relatively low cost [1]. They are composed of semiconductor devices that operate in the linear region, besides having a transformer for galvanic isolation and a variable resistor
[2]. However, they have some undesirable characteristics, such as low efficiency, high weight and volume of passive components compared to the switched sources and the size and losses of the transformer operating at the power supply frequency (low frequency) [1].

Switching sources are the main study subject of power electronics. They are based on the use of switchingoperated semiconductor devices to control energy flow and the conversion of voltage and current waveforms between sources and loads. Because they operate at generally high switching frequencies, they use less robust inductive components in their circuits, thus reducing the size and weight of the equipment. Two other qualities that stand out in this type of voltage source are the high efficiency and the ease of achieve other outputs [1]. Table I shows some differences between linear and switched sources.

The evolution of logic controllers applied on power electronics, allowed the development of several programmable voltage source topologies, which can supply voltages that follow the established references, whether continuous or alternating in nature.

Table I - Comparative summary between switched sources and linear sources [1].

\begin{tabular}{|c|c|c|}
\hline Feature & $\begin{array}{c}\text { Switching-mode } \\
\text { power suplly }\end{array}$ & $\begin{array}{c}\text { Linear power } \\
\text { supply }\end{array}$ \\
\hline Yield & Higher than $80 \%$ & 30 a $60 \%$ \\
\hline Electromagnetic noise & Substatntial & None \\
\hline Dynamic Response & Slow & Fast \\
\hline Number of outputs & Various & Only one \\
\hline
\end{tabular}

Such devices have fundamental importance in the study of voltage sags and oscillations, as well as in the evaluation of the effects arising from the presence of harmonics, since they are capable of generating such disturbances in a controlled manner.

A major drawback of voltage and current sources based on linear power amplifiers, analog controllers and frequency oscillators is that because they have an LC filter in the circuit, they have the output power and the frequency of the generated signal limited to it [2]. Such 
fact may make the use of these types of sources impracticable depending on the required action.

One type of programmable source that has tremendous versatility and quality coupled with its ease of construction is the Buck EIE topology-based converter, see Figure 1. Such devices are capable of individually controlling the inductor current as well as the output capacitor voltage. that make up your circuit. In this way, they can make the output voltage practically immune to load variations [1].

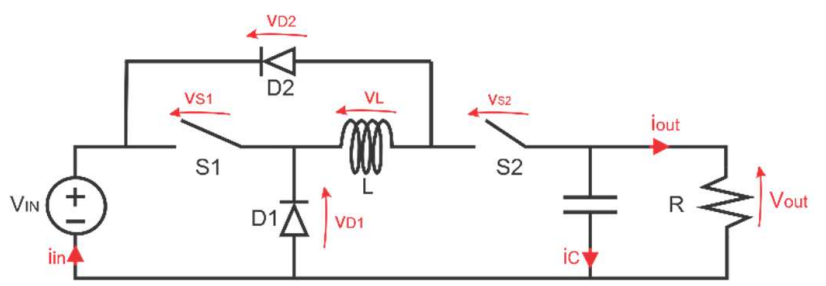

Fig. 1. Buck EIE Converter Topology

The present work will address the use of Buck EIE converters associated with a power factor pre-regulation stage and harmonic current distortion involving a hybrid rectifier circuit, illustrated in Figure 2. Such a device consists of an uncontrolled single-phase rectifier (Ret -1) associated in parallel with a switched single-phase converter (Ret-2).

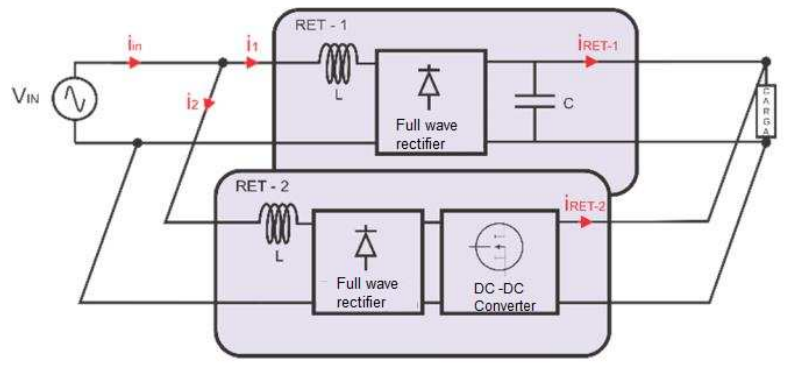

Fig. 2. Single phase hybrid rectifier structure.

The main benefit provided by hybrid rectifiers is the combination of weight and volume reduction from high frequency switched converters with the simplicity and robustness of uncontrolled diode converters [3]. The other advantages of using hybrid rectifiers are:

1) High throughput of overall structure, since switched converters process less of the active power delivered to the load;

2) Lower cost compared to unitary PF switched preregulating converters, since the semiconductor components used in these topologies are designed for rated power;

3) Greater flexibility to comply with IEC610003-2 as the current to be drained from the $\mathrm{AC}$ mains power may vary in shape according to desired DHTI;

\section{Metodology}

This section presents the structures that make up the Buck EIE inverter and the single-phase hybrid rectifier, as well as the specification of their energy storage elements and electronic switch control mechanisms.
A. Working Principle of Single-Phase Hybrid Rectifier The single-phase hybrid rectifier illustrated in Figure 2 has two identical full-wave rectifier bridges. The average output voltage $\left(\mathrm{V}_{\text {med }}\right)$ of each bridge is ideally given (disregarding diode losses) by:

$$
V_{\text {med }}=2 \cdot \frac{V_{\text {peak }}}{\pi}
$$

Where Vmed is the average voltage value after rectifier bridge and Vpeak - Mains voltage peak value. The theoretical waveforms of each step of the uncontrolled rectifier are shown in Figure 3.

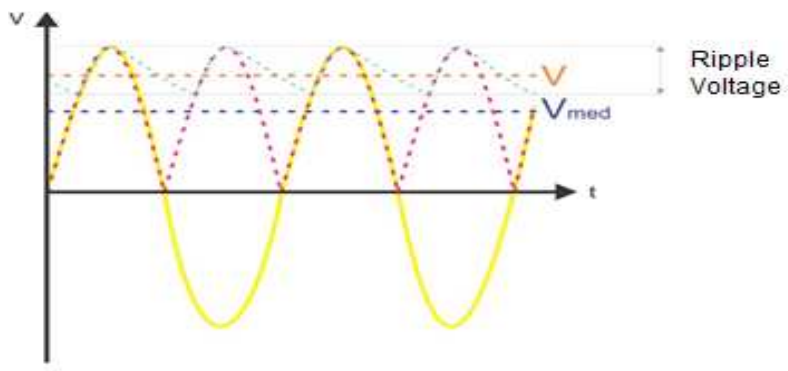

Fig. 3. Waveforms resulting from each uncontrolled rectifier step.

However, the stress after rectification, although of a continuous nature, has a very large voltage ripple. To alleviate such an effect, the use of a capacitive filter is of paramount importance.

Described filtering of the rectified wave causes an increase in the average value of the output voltage given by (1) depending on the impedance connected to it, since the larger the charge, the slower the capacitor will discharge, increasing the average voltage value. filtered (V filtered).

As for the switched DC-DC converter, the Single Ended Primary Inductance Converter (SEPIC) converter was chosen because it presents current source behavior, that is, the imposition of the desired current waveform does not depend strongly on the static gain of the converter [3]. Although in the present work such a converter acts only as a voltage depressor, it has the versatility of operating as a voltage elevator as well. The inductor L1 of the Sepic converter will be allocated before the rectifier bridge, however, all equation will be done as if it were allocated in the position shown in Figure 4, in order to simplify the modelling.

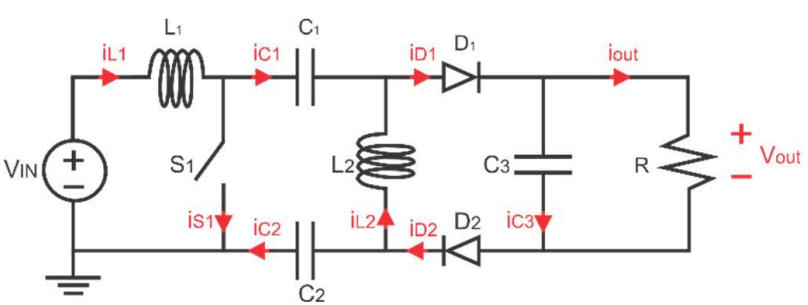

Fig. 4. Sepic Converter.

The controlled rectifier operates in a manner that always follows the output voltage of the uncontrolled rectifier. In addition, it aims to drain a current $\left(i_{2}\right)$ that makes the total current drained from the supply network $\left(i_{\text {in }}\right)$ as close as 
possible to a sine wave. this is in phase with the mains voltage to increase the power factor and consequently the overall structure yield. From Figure 2 it is clear that the input current $\left(i_{\text {in }}\right)$ is the composition of currents $i_{1}$ and $i_{2}\left(i_{1}\right.$ plus $i_{2}$ ), highlighting the fact that the waveform of current $\mathrm{i}_{2}$ is directly responsible for the final characteristic of the drain current. AC power supply. For this purpose, it is necessary to establish a reference of sine current moored in phase with the supply voltage.

Figure 5 illustrates the operation of the hybrid circuit in each of the steps described below:

1) From 0 to $\mathrm{t} 1$, the $\mathrm{DC}$ bus voltage is greater than the input voltage, so the rectifier bridge diodes of the uncontrolled rectifier are reversed polarized;

2) From $t 1$ to $t 2$, the input voltage becomes higher than the DC bus voltage, causing the uncontrolled rectifier bridge diodes to conduction, thus increasing current $i_{1}$. At this moment, the uncontrolled rectifier begins to contribute the total power delivered to the "load", causing the contribution of the switched converter to decrease.

3) From t2 to t3, only the uncontrolled rectifier provides power to the "load" due to the fact that the difference between the sinusoidal current reference with the feedback signal is practically zero, thus disabling the switched converter. Therefore, the network drain current $\left(i_{\text {in }}\right)$ in this range is current $i_{1}$.

4) From $t 3$ to $t 4$, the switched converter is enabled again due to the decrease in current $i_{1}$, which deviates from the sinusoidal current reference in this period.

5) From $t 4$ to $\pi$, the rectifier bridge diodes of the uncontrolled rectifier are again blocked by the DC bus voltage, causing only the switched converter to provide power to the load.

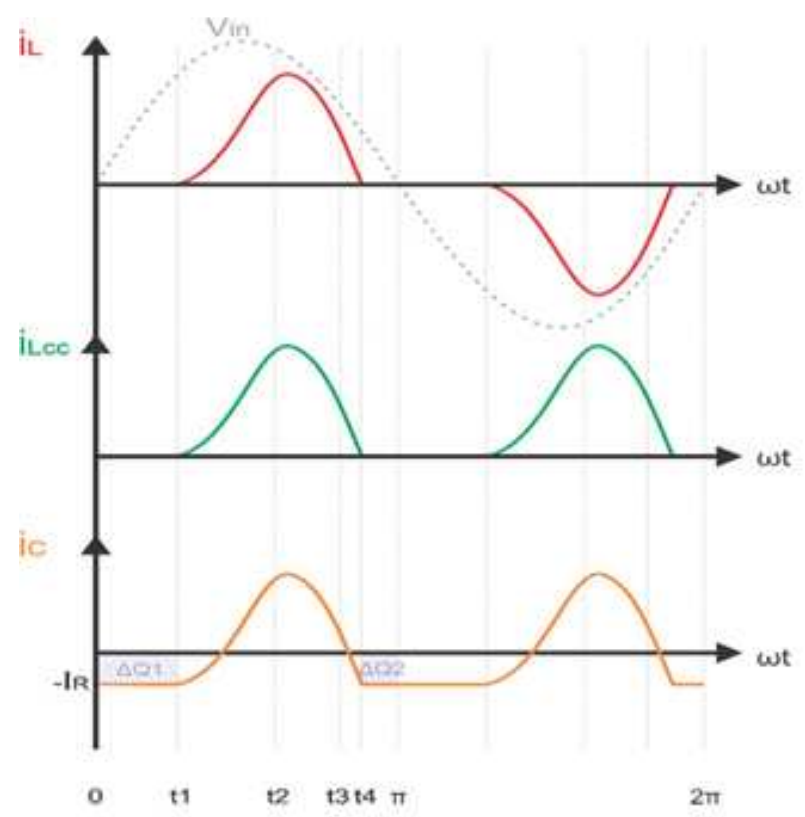

Fig. 5. Theoretical waveforms of the $i_{1}, i_{2}$ and in currents that make up the single phase hybrid rectifier

\section{B. Buck EIE Inverter}

A Buck EIE converter is capable of supplying a load connected to it with a single polarity voltage. In order to meet one of the proposed objectives of this work, which is to supply the load with a voltage that follows a preestablished voltage reference that can have its value varied rapidly, whether of continuous or alternating nature, it is necessary to use two converters. Buck EIE operating at each half voltage of the output voltage, sharing the same output capacitor.

Unlike illustrated by Figure 2, the proposed single-phase hybrid rectifier will not directly feed the load. Each of the two rectifier circuits will supply power to a Buck EIE converter. The arrangement formed by the set of two Buck EIE converters form the Buck EIE inverter. The Buck EIE converter connected to the uncontrolled rectifier will be responsible for increasing the voltage in the load, while the converter connected to the switched rectifier will be in charge of decaying the voltage supplied to the load (when in operation it delivers negative voltage to the output capacitor, decreasing the present voltage. the same).

In the first stage of operation, switches S1 and S2 are driving and switches S3 and S4 are not, as shown in Figure 6. The energy stored in the L1 inductor is transferred to the charge and capacitor by positively charging it. Simultaneously, if there is energy stored in the inductor L2, it will be returned to the source $\left(\mathrm{V}_{\mathrm{in}-2}\right)$ through diodes D3 and D4 [4]-[7].

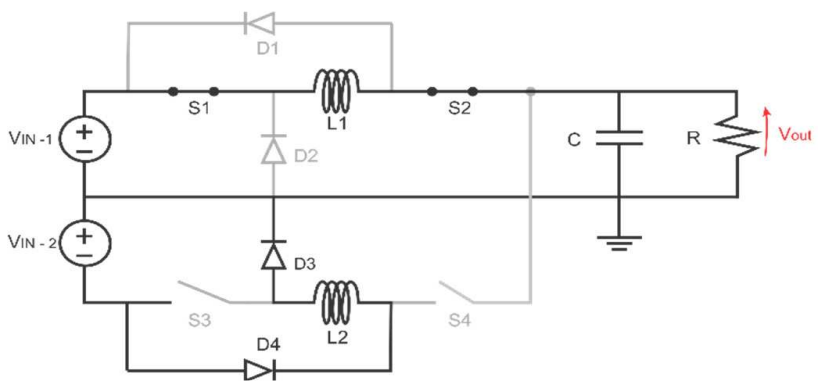

Fig. 6 . Buck EIE inverter first stage of operation

In the second stage, switches S3 and S4 are on, while S1 and S2 are off, see Figure 7. At this time inductor L2 acts as a current source, causing the voltage stored in the capacitor to decay. Any energy stored in L1 will be returned to the Vin-1 power supply via diodes D1 and D2 [4]-[7].

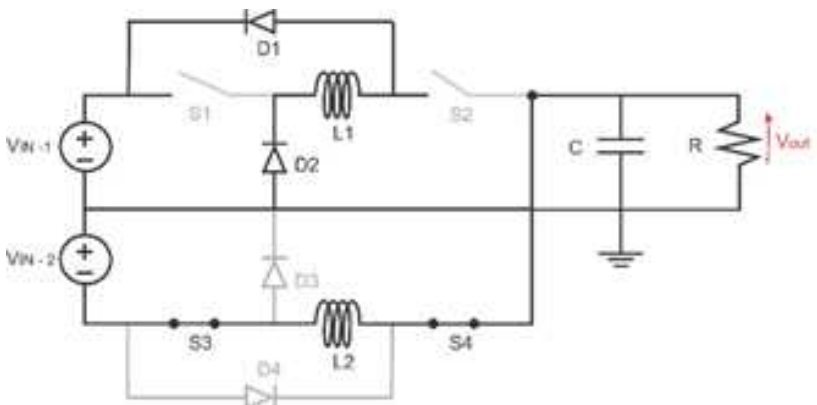

Fig. 7. Buck EIE inverter second stage of operation 


\section{Component sizing}

The design of the single-phase hybrid rectifier and Buck EIE inverter was based on the desired input and output voltage of each step, obeying the ripple levels acceptable. The complete circuit described in this paper is illustrated in Figure 8.

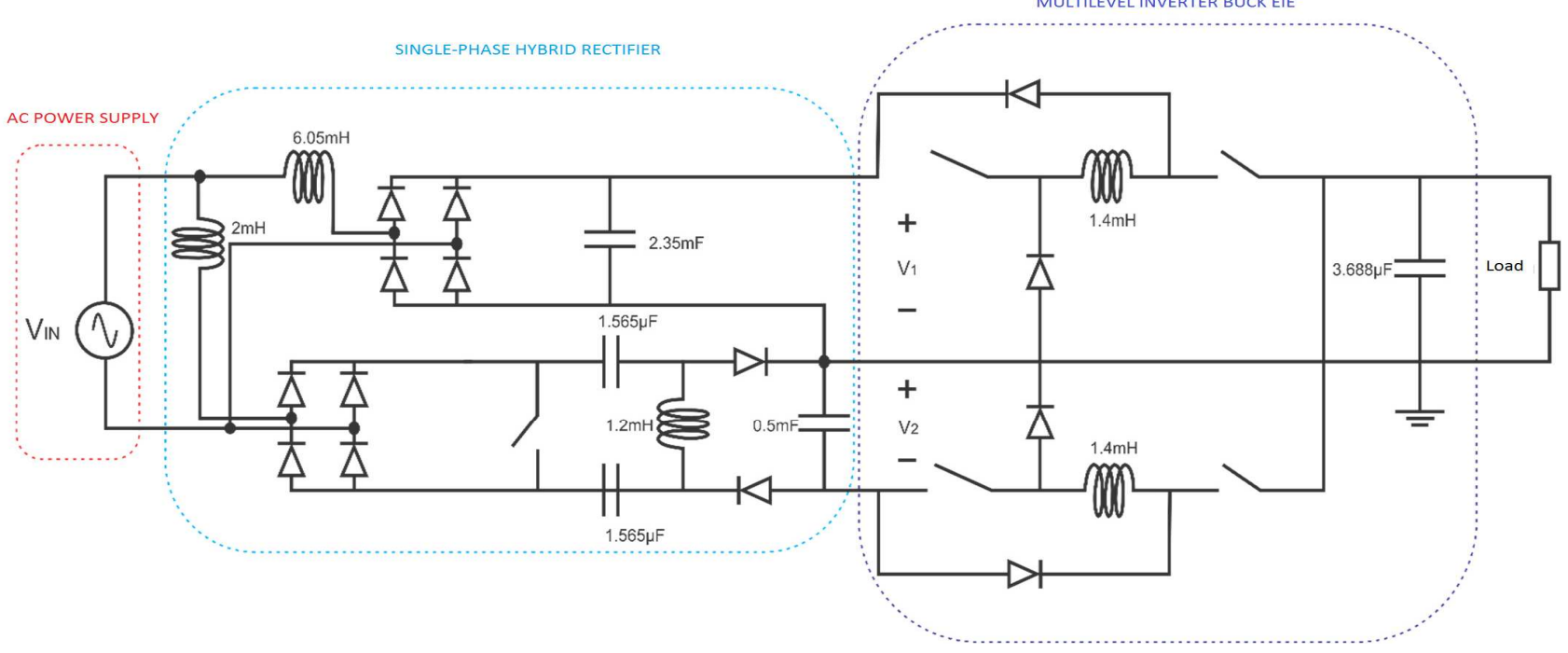

Fig, 8. Buck EIE multi-level inverter connected to a PFC stage consisting of a single phase hybrid rectifier

Table II. - Design Criteria

\begin{tabular}{|c|c|c|c|}
\hline Parameters & $\begin{array}{c}\text { Uncontrolled } \\
\text { Rectifier }\end{array}$ & $\begin{array}{c}\text { Controlled } \\
\text { Rectifier }\end{array}$ & $\begin{array}{c}\text { Buck EIE } \\
\text { Converter }\end{array}$ \\
\hline $\begin{array}{c}\text { Input } \\
\text { Voltage }\end{array}$ & $180 \mathrm{~V}$ (peak) & $180 \mathrm{~V}$ (peak) & $170 \mathrm{~V}$ \\
\hline $\begin{array}{c}\text { Output } \\
\text { Voltage }\end{array}$ & $170 \mathrm{~V}$ & $170 \mathrm{~V}$ & $\begin{array}{c}100 \mathrm{~V} \\
\text { (peak) }\end{array}$ \\
\hline $\begin{array}{c}\text { Output } \\
\text { Power }\end{array}$ & $70 \mathrm{~W}$ & $50 \mathrm{~W}$ & $50 \mathrm{~W}$ \\
\hline $\begin{array}{c}\text { Switching } \\
\text { Frequency }\end{array}$ & - & $100 \mathrm{KHz}$ & $100 \mathrm{KHz}$ \\
\hline $\begin{array}{c}\text { Current } \\
\text { Variation }\end{array}$ & - & $\begin{array}{c}\mathrm{L}_{1}=78,40 \% \\
\mathrm{~L}_{2}=193,95 \%\end{array}$ & $\mathrm{~L}=40 \%$ \\
\hline $\begin{array}{c}\text { Voltage } \\
\text { Ripple }\end{array}$ & $\mathrm{C}=0.5 \%$ & $\begin{array}{c}\mathrm{C}_{1}=0,98 \% \\
\mathrm{C}_{2}=0,98 \% \\
\mathrm{C}_{3}=2,066 \%\end{array}$ & $\mathrm{C}=1 \%$ \\
\hline
\end{tabular}

Based on the criteria adopted in Table II and the design expressions deduced earlier, the projected values for each part of the circuit are shown in Tables III, IV, and V. As will be seen in subsection $\mathrm{E}$, control of both the controlled rectifier and the inverter This is done using analog comparators (hysteresis control), so there is no fixed switching frequency for either of the two electronic switches. However, for the purpose of sizing the energy storage elements, a switching frequency of $100 \mathrm{kHz}$ will be considered for the mentioned circuits.

To design the inductance value and capacitance of the uncontrolled rectifier circuit, the parameters shown in Table II were used. To calculate the inductance, it was first necessary to calculate the time $\mathrm{t} 1$ and $\mathrm{t} 4$ shown in Figure 8.
The first instant was calculated using the expression (6), and $\mathrm{t} 4$ was calculated using the numerical method using the Matlab software (version of student), finding the real root of the function given by (8). The calculated value of $\mathrm{t} 1$ is $3.2783 \mathrm{~ms}$ and that of $\mathrm{t} 45.9536 \mathrm{~ms}$.

Table. III. - Projected values for uncontrolled rectifier

\begin{tabular}{|c|c|}
\hline Projected variables & Projected Values \\
\hline Capacitor $(\mathrm{C})$ & $2,35 \mathrm{mF}$ \\
\hline Inductor $(\mathrm{H})$ & $6,05 \mathrm{mH}$ \\
\hline
\end{tabular}

Table IV. - Projected values for the controlled rectifier

\begin{tabular}{|c|c|}
\hline Projected variables & Projected Values \\
\hline Duty Cycle & 0.5973 \\
\hline Capacitor $\left(\mathrm{C}_{1}\right)$ & $1,565 \mathrm{uF}$ \\
\hline Capacitor $\left(\mathrm{C}_{2}\right)$ & $1,565 \mathrm{uF}$ \\
\hline Capacitor $\left(\mathrm{C}_{3}\right)$ & $0,5 \mathrm{mF}$ \\
\hline Inductor $\left(\mathrm{L}_{1}\right)$ & $2 \mathrm{mH}$ \\
\hline Inductor $\left(\mathrm{L}_{2}\right)$ & $1,2 \mathrm{mH}$ \\
\hline
\end{tabular}

Table V. - Projected values for the Buck EIE inverter

\begin{tabular}{|c|c|}
\hline Projected variables & Projected Values \\
\hline Duty Cycle & 0.6312 \\
\hline Capacitor (C) & $3,688 \mathrm{uF}$ \\
\hline Indutuctors (L1 and L2) & $1,4 \mathrm{mH}$ \\
\hline Load Resistance & $100 \Omega$ \\
\hline
\end{tabular}




\section{Control strategy}

The opening and closing of the Sepic converter and Buck EIE inverter electronic keys are individually controlled. In both cases, hysteresis modulation is used.

\section{1) Controlled rectifier control}

The control of the Sepic converter is performed using the circuit shown in Figure 9. The reference current $\left(\mathrm{I}_{\mathrm{ref}}\right)$ is generated using a Phase-Locked Loop (PLL), which generates a moored current reference (in phase) with the input supply voltage. This signal is multiplied by the output signal of a PI controller which is responsible for minimizing the error between sensed $\left(\mathrm{V}_{\text {out }}\right.$ (ret-2)) and reference $\left(\mathrm{V}_{\text {out (ret-1) }}\right)$ output voltages. Then, the resulting signal is multiplied by the set reference current $\left(i_{\text {ref }}\right)$ and shortly thereafter, it is compared to the absorbed current from the mains $\left(i_{\text {in }}\right)$. The analog comparator output will determine whether the circuit switch will remain closed or open at that time.

It is worth mentioning that the PI controller was chosen for its ease of digital implementation and the fact that it serves this application well. However, for future practical applications, it could be used the resonant proportional controller because it has shown best dinamical response against sinusoidal references.

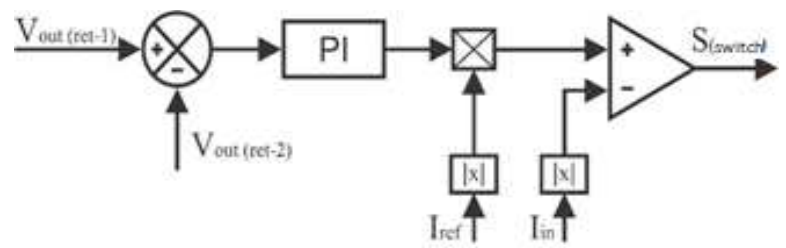

Fig. 9. Sepic converter control circuit.

By manipulating the input current amplitude, the output voltage is controlled. Thus, it is clear that this control loop makes the controlled rectifier circuit operate both as input current source as well as output voltage source.

\section{2)Buck EIE Inverter Control}

Inverter control is carried out simply. The reference voltage (desired voltage, $\mathrm{V}_{\text {ref }}$ ) is compared to the circuit output voltage $\left(\mathrm{V}_{\text {out }}\right)$, and the comparator output will determine which EIE cell will be active. Thus, for times when the reference voltage is greater than the output voltage, switches $\mathrm{S} 1$ and $\mathrm{S} 2$ are closed and S3 and S4 open, for the other condition, the opposite happens, S3 and S4 lead and S1 and S2 no. The described control circuit is represented by Figure 10.

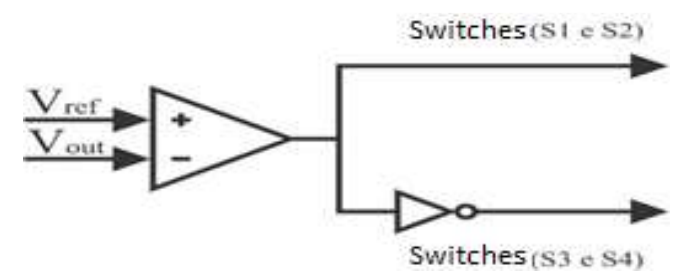

Fig. 10. Buck EIE inverter control circuit.

\section{Results}

The figure 11 shows the amplitude of currents $i_{\text {in }}, i_{1}$ and $i_{2}$ symbolized in Figure 2. Total input current $\left(i_{\text {in }}\right)$ is the direct sum of the current drained by the uncontrolled rectifier $\left(i_{1}\right)$ and that of the controlled rectifier $\left(i_{2}\right)$.

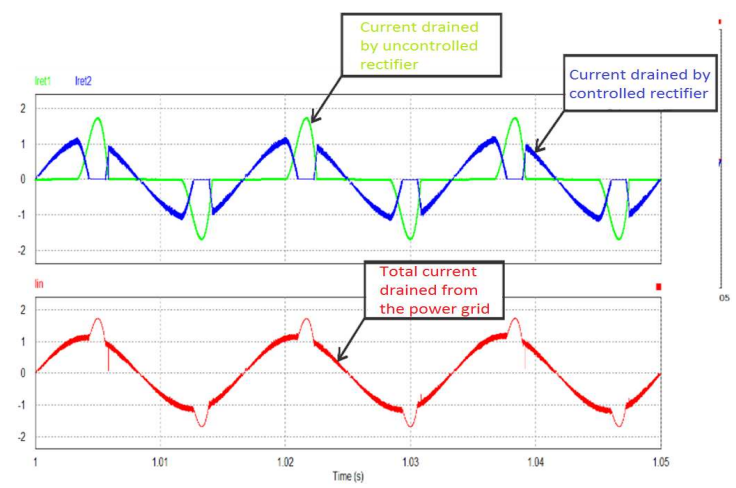

Fig. 11. Waveforms obtained in simulation of the $i_{1}, i_{2}$ and currents that make up the single phase hybrid rectifier.

From the analysis of Figure 12, it is possible to verify that the input voltage $\left(\mathrm{V}_{\text {in }}\right)$ and the current drained by the network $\left(i_{\text {in }}\right)$ are in phase and the drained current looks very close to the sinusoidal, ensuring high power factor and low harmonic distortion. thus meeting the main objective proposed in this paper.

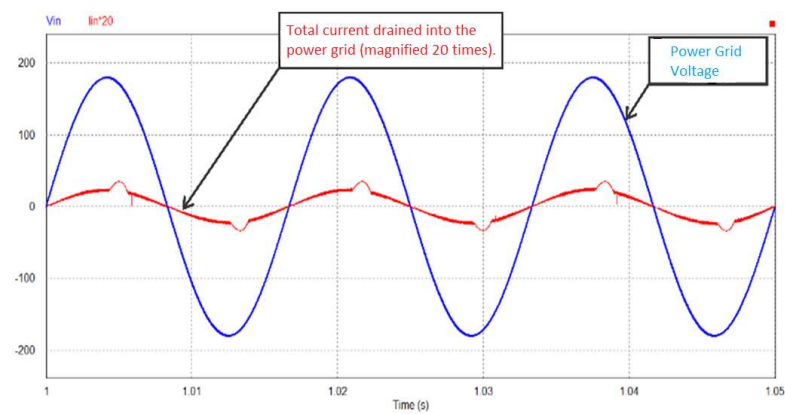

Fig. 12. Waveforms obtained by simulating the voltage supplied by the mains and the current drawn from it

The figure 13 shows the output voltage of the Buck EIE invertir as well as the voltages at the circuit outputs rectifiers. The proposed output reference voltage was a 60 $\mathrm{Hz}$ sinusoid and 100 Volts peak. The output voltage represented by the red curve is completely according to the established reference parameters.

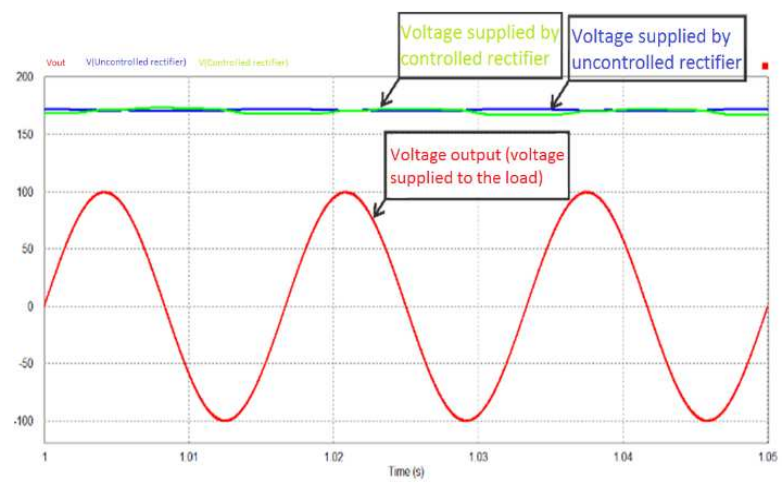

Fig. 13. Waveforms obtained by simulating the voltage supplied load, the output voltage of the controlled rectifier and the noncontrolled. 
The Buck EIE inverter is capable of generating output voltages of various shapes and frequencies. Figure 14 shows the resulting output voltage for voltage reference at $20 \mathrm{~Hz}$ and Figure 15 at $200 \mathrm{~Hz}$, both with 100 peak voltage.

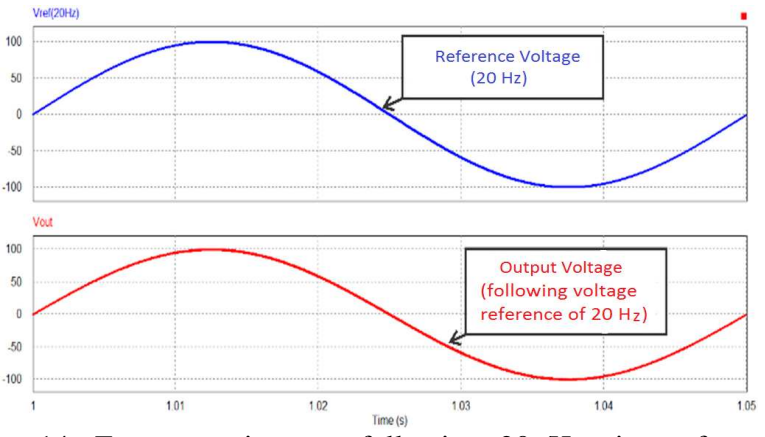

Fig. 14. Frequency inverter following $20 \mathrm{~Hz}$ sine reference voltage (simulated waveforms).

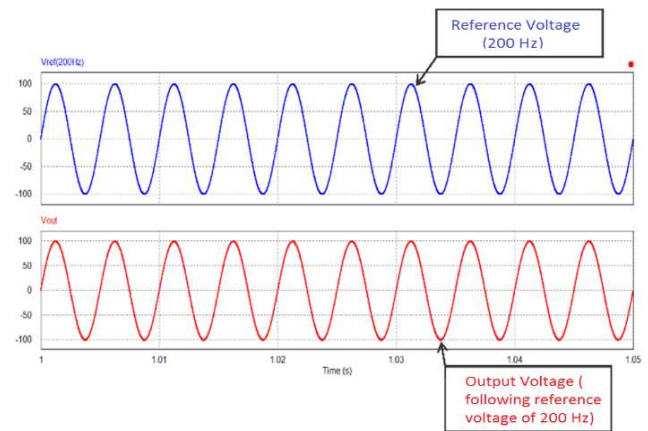

Fig. 15. Frequency inverter following $200 \mathrm{~Hz}$ sine reference voltage (simulated waveforms).

As mentioned earlier, this inverter topology becomes very useful for studies in the field of power quality, especially when the scope of study is on the presence and effects caused by the presence of harmonics in the power grid. Figure 16 shows the inverter following a voltage reference composed of sine harmonics, specified in Table VI.

Table VI. - Characteristic of harmonic components present in the established voltage reference

\begin{tabular}{|c|c|c|}
\hline Harmonic Order & Frequency (Hz) & Peak Voltage (V) \\
\hline Fundamental & 60 & 70 \\
\hline Third & 180 & 30 \\
\hline Fifth & 300 & 50 \\
\hline Seventh & 420 & 10 \\
\hline
\end{tabular}

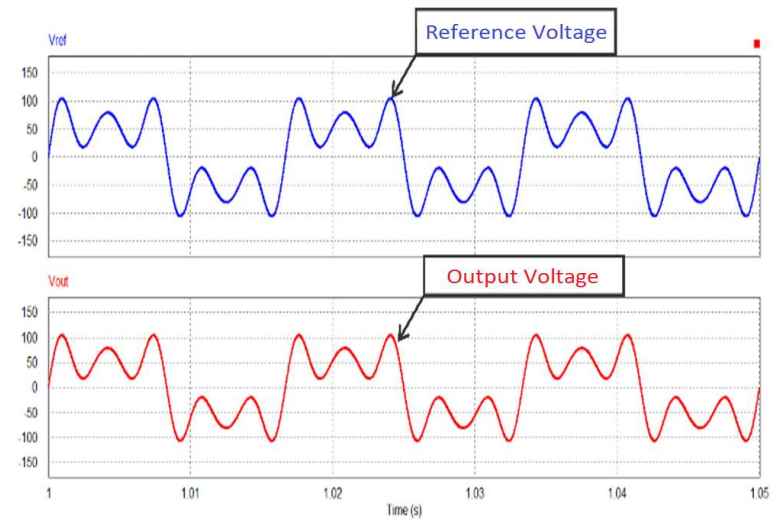

Fig. 16. Frequency inverter following reference voltage with presence of third, fifth and seventh order harmonics

\section{Conclusions}

A power factor correction stage proposal based on the use of a single phase hybrid rectifier to supply a Buck EIE multi-level inverter was presented. The PFC stage is performed by the association of a controlled rectifier (Sepic) and an uncontrolled one, which is responsible for increasing the overall structure yield. This circuit has as its main function to ensure that the input voltage and current are in phase, resulting in a high power factor (very close to the unit). In addition, it is desired that the output voltages of the hybrid rectifier be kept at a constant value, and that the input current waveform presents low harmonic distortion.

The results obtained through simulations performed in the PSIM v.11 software were very satisfactory, since the Buck EIE inverter provided the desired voltage for the load and the current drained from the mains, besides being in phase with the voltage, presented low DHT.

\section{References}

[1] Padula, A. S. Desenvolvimento de uma fonte programável com controle baseado na realimentação de variáveis de estado utilizando alocação de polos. 2016. Undergraduate Thesis - Electrical Engineering Faculty, Universidade Federal do Triângulo Mineiro, Uberaba, 2016.

[2] Dias, C. O. Desenvolvimento de estágio PFC utilizando a associação de conversores Sepic e Cuk para conexão de fonte programada de alimentação baseada em conversor do tipo Buck EIE. 2018. Undergraduate Thesis - Electrical Engineering Faculty, Universidade Federal do Triângulo Mineiro, Uberaba, 2018.

[3] Rodrigues, B. R. Retificador híbrido monofásico de alta potência e elevado fator de potência com controle digital utilizando DSP. 2010. Undergraduate Thesis - Electrical Engineering Faculty - Universidade Federal de Uberlândia, Uberlândia, 2010.

[4] Costa, N. M. A.; Freitas, L. C.; Junior, J. B. V.; Coelho, E. A. A.; Farias, V. J.; Freitas, L. C. G. Uma nova abordagem para inversores multiníveis em cascata utilizando células de comutação EIE. VIII Conferência de Estudos em Engenharia Elétrica, Universidade Federal de Uberlândia, Uberlândia, 2010. Disponível em:

https://www.peteletricaufu.com/static/ceel/doc/artigos/ar tigos2010/ceel2010_20.pdf >. Acesso em: 29 jul. 2018.

[5] Costa, N. M. A.; Freitas, L. C.; Coelho, E. A. A.; Freitas, L. C. G; Melo, F. 'Multilevel inverter based on cascaded association of Buck EIE inverters', IET Power Electronics, 2013, 6, (6), p. 1165-1174.

[6] Costa, N. M. A.; Freitas, L. C.; Coelho, E. A. A.; Freitas, L. C. G; Melo, F. Experimental analysis of a cascaded multilevel inverter using Buck EIE converters. Twenty-Seventh Annual IEEE Applied Power Electronics Conference and Exposition, 2012, p. 16591666.

[7] Bissochi Junior, C. A. Proposta de uma Nova Família de Conversores Denominados EIE: Aplicações em Áudio, Análise Genérica e Resultados Experimentais. 2003. 330 f. Tese (Doutorado em Engenharia) - Curso de Engenharia Elétrica, Universidade Federal de Uberlândia, Uberlândia 2003. 